\title{
ALAT PERAGA ENGKLEK SEBAGAI UPAYA PENINGKATAN KEMAMPUAN MENGGALI PENGETAHUAN BARU SISWA
}

\author{
Ella Agustina, Imaniar Purbasari, dan Ristiyani
}

Universitas Muria Kudus

Email: ellaagustina080@gmail.com

\section{Info Artikel}

Sejarah Artikel:

Diserahkan 30 Juli 2020

Direvisi 12 Agustus 2020

Direvisi 9 November 2020

Disetujui 15 November 2020

\section{Keywords:}

ability to explore new

knowledge,

engklek as media.

\section{Abstract}

This study aims to describe the increase in the ability to explore new knowledge of students and teaching skills of teachers by using the engklek as media in grade IV SD IT Al-Hikmah Mayong.

The class action research is carried out for two cycles, each cycle having two meetings and consisting of four stages, namely planning, acting, observing, and reflecting. Class IV research subjects at Al-Hikmah Mayong Elementary School with a total of 36 students. The independent variable in this study is the engklek as media, while the dependent variable is the ability to explore new knowledge. Data collection techniques using tests (written) and nontest include observation, interviews, and documentation. The analysis used is quantitative data analysis and qualitative data analysis.

The results of the study showed that using a engklek as media could improve students ability to explore new knowledge and teaching skills. The ability to explore new knowledge of students has increased from cycle I $64 \%$ and cycle II to $92 \%$. There is an increase in teacher teaching skills in the first cycle to get a success rate of $70 \%$ with enough categories, then in the second cycle to get a success rate of $94 \%$ with very good categories.

\begin{abstract}
Abstrak
Penelitian ini bertujuan untuk mendeskripsikan peningkatan kemampuan menggali pengetahuan baru siswa dan keterampilan mengajar guru dengan menggunakan alat peraga engklek pada kelas IV SD IT Al-Hikmah Mayong.

Penelitian tindakan kelas dilaksanakan sebanyak dua siklus, setiap siklus terdapat dua pertemuan dan terdiri dari empat tahapan yaitu perencanaan, pelaksanaan, pengamatan, dan refleksi. Subjek penelitian yaitu kelas IV SD IT Al-Hikmah Mayong dengan jumlah 36 siswa. Variabel bebas penelitian yaitu alat peraga engklek, sedangkan variabel terikatnya yakni kemampuan menggali pengetahuan baru. Teknik pengumpulan data menggunakan tes (tertulis) dan nontes meliputi observasi, wawancara, dan dokumentasi. Analisis yang digunakan yaitu analisis data kuantitatif dan analisis data kualitatif.

Hasil penelitian menunjukkan bahwa dengan menggunakan alat peraga engklek dapat meningkatkan kemampuan menggali pengetahuan baru siswa dan keterampilan mengajar guru. Kemampuan menggali pengetahuan baru siswa mengalami peningkatan dari siklus I $64 \%$ dan siklus II menjadi $92 \%$. Keterampilan mengajar guru terdapat peningkatan pada siklus I memperoleh persentase keberhasilan $70 \%$ dengan kategori cukup, kemudian pada siklus II memperoleh persentase keberhasilan 94\% dengan kategori sangat baik.
\end{abstract}

(C) 2020 Universitas Muria Kudus 


\section{Ella Agustina, Imaniar Purbasari, dan Ristiyani \\ ALAT PERAGA ENGKLEK SEBAGAI UPAYA PENINGKATAN KEMAMPUAN ... WASIS: Jurnal Ilmiah Pendidikan. Volume 1, Nomor 2, November 2020, hlm. 93-98}

\section{PENDAHULUAN}

Pada kurikulum 2013 guru sebagai fasilitator pembelajaran berperan untuk memudahkan peserta didik dalam kegiatan pembelajaran (Marwiyah dkk, 2018). Proses pembelajaran diharapkan menarik dengan adanya inovasi baru agar siswa berperan aktif sehingga mudah memahami materi yang disampaikan oleh guru.

Dalam mempelajari Bahasa Indonesia yang harus dikuasai siswa dari empat keterampilan berbahasa salah satunya adalah membaca. Yogyantoro (2016) menyebut pembelajaran bahasa Indonesia mencakup empat keterampilan berbahasa yaitu: 1) keterampilan menyimak, 2) keterampilan berbicara, 3) keterampilan membaca, dan 4) keterampilan menulis. Ada berbagai tujuan seseorang dalam melakukan kegiatan membaca, diantaranya yaitu untuk menggali informasi atau makna dari bacaan

Menurut Linze dalam (Nazilah dkk, 2017) membaca merupakan seperangkat keterampilan berpikir untuk menggali makna yang tekandung dalam bacaan. Pada kelas IV, salah satu kompetensi dasar yang harus dikuasai siswa adalah menggali pengetahuan baru yang terdapat pada teks nonfiksi.

Teks nonfiksi adalah teks yang isinya bersifat faktual, hal-hal yang terkandung di dalamnya berasal dari fakta yang benar-benar ada dalam kehidupan (Astuti, 2019). Pada dasarnya teks nonfiksi merupakan sebuah karangan yang berdasarkan fakta dalam bentuk cerita nyata dan benar terjadi di dalam kehidupan. Selaras dengan pendapat Mudikawaty dkk (2018) yang menjelaskan bahwa teks nonfiksi merupakan sebuah hasil karangan dalam bentuk cerita kehidupan setiap hari yang dituliskan menjadi sebuah cerita.

Rajin membaca sangat ditentukan oleh minat, namun kenyataannya minat baca yang dimiliki siswa tampak rendah, karena dalam keseharian aktivitas bermain lebih mendominasi. Guru dituntut memotivasi siswa dalam pembelajaran dengan memahami sejumlah media pembelajaran, penggunaan media pembelajaran dianggap penting karena dapat membantu guru dan mempermudah dalam penyampaian materi pelajaran sehingga mempermudah dalam mencapai tujuan pembelajaran.

Salah satu untuk mempermudah penyampaian materi pelajaran dengan menggunakan permainan, dapat berupa permainan tradisional yang dimainkan dengan alat seadanya dan memiliki ciri kedaerahan asli sesuai dengan tradisi budaya setempat ataupun permainan modern yang dilakukan menggunakan alat-alat teknologi yang telah berkembang. Permainan tradisional pada kenyataannya dapat digunakan sebagai sarana pendidikan karena dapat membantu perkembangan keterampilan, baik keterampilan sosial maupun pengetahuan. Menurut Hapidin dan Yenina (2016) permainan tradisional merupakan bentuk ekspresi dan apersiasi dari tradisi masyarakat dalam menciptakan situasi serta kegiatan yang gembira dan menyenangkan.

Berdasarkan hasil observasi yang dilakukan masih ditemukan beberapa kendala dalam pelaksanaan pembelajaran kurikulum 2013 di SD IT Al-Hikmah Mayong, diketahui bahwa penggunaan model pembelajaran kurang bervariatif, kurangnya antusias siswa mengikuti pembelajaran sehingga suasana kelas tidak kondusif, dan kurangnya penggunaan media. Sehingga siswa masih bergantung pada guru, karena guru mendominasi pembelajaran, hal tersebut berdampak pada nilai siswa yang rendah.

Berdasarkan nilai ulangan tengah semester (UTS) diketahui bahwa dari 36 siswa terdapat 14 siswa yang mampu mencapai kriteria ketuntasan minimal (KKM) atau jika di persentase hanya $39 \%$, sementara 22 siswa lainnya belum mencapai KKM atau jika di persentase sebanyak $61 \%$. SD IT Al-Hikmah Mayong memiliki kriteria ketuntasan minimal (KKM) sebesar 70.

Melihat persoalan tersebut, maka perlu perbaikan dalam proses pembelajaran. Penggunaan alat peraga engklek dijadikan solusi untuk membantu siswa lebih memahami materi yang disampaikan oleh guru. Menurut Murdiyanto dan Muhatma (2014) alat peraga adalah alat yang digunakan guru dalam mengajar untuk membantu memperjelas materi pelajaran yang disampaikan kepada siswa dan mencegah verbalisme pada diri siswa. Senada dengan pendapat Nasution dalam (Rusmawati, 2017) alat peraga adalah alat pembantu dalam mengajar agar lebih efektif.

Permainan engklek adalah permainan untuk mengembangkan kemampuan anak melompat dengan satu kaki (Wiranti dan Mawarti, 2018). Permainan engklek dilakukan oleh dua orang atau lebih dan kegiatannya dapat melatih gerak motorik, serta melatih interaksi sosial antara pemain yang satu dengan pemain lainnya (Juliarto dkk, 2020). Hal tersebut sejalan dengan yang disampaikan oleh Mardayani dkk (2016) engklek dapat melatih kemampuan 


\section{Ella Agustina, Imaniar Purbasari, dan Ristiyani \\ ALAT PERAGA ENGKLEK SEBAGAI UPAYA PENINGKATAN KEMAMPUAN ... \\ WASIS: Jurnal Ilmiah Pendidikan. Volume 1, Nomor 2, November 2020, hlm. 93-98}

motorik kasar anak, kejujuran, kerjasama, kekompakkan, keterampilan, ketangkasan, keseimbangan, dan sikap serta dapat melatih jiwa kesosialan anak dalam menghadapi kehidupan bermasyarakat.

Penggunaan alat peraga engklek menciptakan belajar sambil bermain, hal tersebut juga sepadan dengan pendapat Vygotsky dalam (Kurniati, 2016) memaparkan kontribusi bermain terhadap perkembangan sejumlah fungsi mental yang tinggi, antara lain yaitu bermain membantu perkembangan kemampuan anak untuk bernalar, suasana bermain dapat menghasilkan ingatan yang lebih baik lagi bagi anak daripada sekedar dalam tugas menamai atau menyentuh objek, dan bermain juga melibatkan interaksi dengan orang lain, hal tersebut sangatlah memfasilitasi perkembangan bahasa anak.

Penelitian mengenai kemampuan membaca dan penggunaan media engklek telah dilakukan oleh beberapa peneliti antara lain oleh Murtono (2014), Hastutik (2015), Kusniati (2015), Supriyati (2015) dan Sari, Chamisijatin, dan Santoso (2019). Namun penelitian yang dilakukan berbeda dengan penelitian tersebut diatas. Adapun tujuan penelitian ini mendeskripsikan peningkatan kemampuan menggali pengetahuan baru siswa dan keterampilan mengajar guru melalui alat peraga engklek pada kelas IV SD IT Al-Hikmah Mayong.

\section{METODE PENELITIAN}

Metode yang digunakan adalah penelitian Tindakan Kelas (PTK). Subjek penelitian yaitu seluruh siswa kelas IV di SD IT Al-Hikmah Mayong dengan jumlah 36 siswa, meliputi 24 siswa laki-laki dan 12 siswi perempuan. Penelitian tindakan kelas (PTK) dilaksanakan dalam bentuk siklus yang terdiri dari empat tahapan sesuai dengan model Arikunto (2014) yakni perencanaan, pelaksanaan, pengamatan, dan reflkesi.

Pada tahap perencanaan, instrumen yang dipakai untuk mengumpulkan data antara lain 1) menyusun silabus dan rencana pelaksanaan pembelajaran (RPP), 2) menyiapkan alat peraga engklek, 3) menyiapkan materi pelajaran, 4) menyusun lembar kerja kelompok (LKK), 5) menyusun kisi-kisi lembar evaluasi, 6) menyusun lembar evaluasi, 7) menyusun kunci jawaban lembar evaluasi, 8) menyusun lembar pengamatan keterampilan guru, dan 9) membuat lembar observasi kemampuan menggali pengetahuan baru.
Tahap pelaksanaan terdiri 2 siklus atau 4 kali pertemuan. Bersamaan dengan tahap pelaksanaan terdapat juga tahap pengamatan untuk mengamati seluruh kegiatan saat proses pembelajaran berlangsung. Sedangkan tahap refleksi merupakan kegiatan untuk mengemukakan kembali apa yang sudah dilakukan, jika terdapat masalah maka dilakukan pengkajian, tindakan, dan pengamatan ulang sehingga permasalahan dapat teratasi.

Sumber data yang dipakai adalah data primer diambil dari nilai akhir siklus I, siklus II, dan lembar pengamatan. Sedangkan data sekunder diambil dari wali kelas IV yang meliputi daftar nama siswa, daftar nilai ulangan tengah semester (UTS), dan buku refrensi materi ajar. Teknik pengumpulan data yang digunakan adalah tes (tertulis) dan nontes meliputi observasi, wawancara, dan dokumentasi.

Validitas data menggunakan teknik expert judgment .dan analisis data yang digunakan yakni analisis data kuantitatif diperoleh dari hasil tes, dan analisis data kualitatif yang dilakukan selama proses pembelajaran. Indikator keberhasilan yang diharapkan untuk kemampuan menggali pengetahuan baru mencapai kriteria ketuntasan minimal (KKM) yakni 70 dengan ketuntasan klasikal $75 \%$ dan keterampilan mengajar guru mencapai kriteria minimal $75 \%$ termasuk dalam kualifikasi baik.

\section{HASIL DAN PEMBAHASAN}

Siklus I dilaksanakan dua kali pertemuan, pertemuan 1 dilaksanakan pada hari Kamis tanggal 20 Februari 2020 dan pertemuan 2 dilaksanakan pada hari Jumat tanggal 21 Februari 2020, sedangkan pada siklus II pertemuan 1 dilaksanakan pada hari Kamis tanggal 27 Februari 2020 dan pertemuan 2 dilaksanakan pada hari Jumat tanggal 28 Februari 2020, dengan alokasi waktu 5x35 menit setiap pertemuannya.

Sebelum melaksanakan proses pembelajaran perlu adanya penyusunan instrumen terlebih dahulu meliputi 1) menyusun silabus dan rencana pelaksanaan pembelajaran (RPP), 2) menyiapkan alat peraga engklek, 3) menyiapkan materi pelajaran, 4) menyusun lembar kerja kelompok (LKK), 5) menyusun kisi-kisi lembar evaluasi, 6) menyusun lembar evaluasi, 7) menyusun kunci jawaban lembar evaluasi, 8) menyusun lembar pengamatan keterampilan guru, dan 9) membuat lembar observasi kemampuan menggali pengetahuan baru. 


\section{Ella Agustina, Imaniar Purbasari, dan Ristiyani \\ ALAT PERAGA ENGKLEK SEBAGAI UPAYA PENINGKATAN KEMAMPUAN ... WASIS: Jurnal Ilmiah Pendidikan. Volume 1, Nomor 2, November 2020, hlm. 93-98}

Berdasarkan analisis yang dilakukan pada setiap siklusnya, ketuntasan klasikal kemampuan menggali pengetahuan baru dengan menggunakan alat peraga engklek pada kelas IV SD IT Al-Hikmah Mayong dapat dilihat pada tabel di bawah ini.

Tabel 1. Ketuntasan Klasikal Kemampuan Menggali Pengetahuan Baru Siklus I dan Siklus II

\begin{tabular}{lll}
\hline No & Pelaksanaan & Ketuntasan Klasikal \\
\hline 1 & Siklus I & $64 \%$ \\
2 & Siklus II & $92 \%$ \\
\hline
\end{tabular}

Pada tabel di atas menunjukkan peningkatan ketuntasan klasikal kemampuan menggali pengetahuan baru di setiap siklusnya. Ketuntasan klasikal siswa pada siklus I mendapat $64 \%$, kemudian meningkat sebesar $28 \%$ pada siklus II menjadi $92 \%$. Dari 36 siswa pada siklus I terdapat 23 siswa yang tuntas, sedangkan pada siklus II jumlah siswa yang mencapai ketuntasan kemampuan menggali pengetahuan baru sebanyak 33 siswa.

Berdasarkan pada siklus I sudah berlangsung baik, tetapi masih ada beberapa kekurangan atau permasalahan seperti siswa kurang fokus dalam menerima materi pelajaran, siswa masih ada yang bergantung pada teman, siswa kurang berani dalam mengemukakan atau mengajukan pertanyaan, dan pada saat pemberian reward siswa tidak mengikuti aturan. Permasalahan tersebut dapat dikarenakan kurang adanya motivasi belajar dari diri siswa, Emda (2017) mengemukakan bahwa motivasi belajar merupakan sesuatu keadaan yang terdapat pada diri seseorang individu dimana ada suatu dorongan untuk melakukan sesuatu guna mencapai tujuan.

Untuk mengatasi permasalahan tersebut guru memberikan motivasi dan penguatan dengan lebih spesifik dalam mengarahkan siswa ketika menerima materi, memberikan bimbingan khusus pada siswa saat berdiskusi dan lebih tegas dalam menyamaratakan pembagian tugas kelompok, lebih berkomunikatif dan berusaha meningkatkan keberanian siswa untuk mengemukakan pendapatnya, lebih tegas dan bijaksana saat berjalannya pemberian reward, serta memperingatkan siswa yang kurang tertib. Berdasarkan hasil refleksi pada siklus I dan dilakukan perbaikan pada siklus II siswa lebih memahami materi, mandiri dan bertanggung jawab dalam mengerjakan tugas, berani mengemukakan pendapatnya, dan tertib dalam mengikuti pembelajaran.

Penggunaan alat peraga engklek menunjukkan peningkatan pada siklus I ke siklus II, karena fungsi alat peraga dapat disimpulkan sebagai alat bantu yang menciptakan proses pembelajaran efektif agar siswa tidak mudah bosan dan mampu memperbesar minat belajar siswa, karena minat belajar siswa sangat dibutuhkan dalam proses pembelajaran. Fauziah dkk (2017) mengemukakan minat merupakan sebuah awal penggerakan untuk siswa dalam belajar yang dapat digunakan untuk mencapai tujuan yang diinginkan.

Penelitian yang dilakukan mempunyai persamaan dan perbedaan dengan penelitian Prasetyawati (2015), penelitian Aliya (2016), penelitian Mardayani dkk (2016), penelitian Hermawan (2018), dan penelitian Rini (2018). Persamaan yang dimaksud adalah keberhasilan dalam meningkatkan hasil belajar pada siswa melalui media permainan tradisional, adapun perbedaannya terletak pada fokus dan hasil penelitian yang diperoleh.

Data hasil pengamatan keterampilan mengajar guru dalam mengelola pembelajaran dengan menggunakan alat peraga engklek pada kelas IV SD IT Al-Hikmah Mayong dapat dilihat pada tabel di bawah ini.

Tabel 2. Keterampilan Mengajar Guru Siklus I Dan Siklus II

\begin{tabular}{lll}
\hline No & Pelaksanaan & Rata-Rata \\
\hline 1 & Siklus I & $69 \%$ \\
2 & Siklus II & $94 \%$ \\
\hline
\end{tabular}

Pada tabel di atas menunjukkan peningkatan di setiap siklusnya dalam mengelola pembelajaran dengan menggunakan alat peraga engklek pada kelas IV SD IT Al-Hikmah Mayong, hasil rata-rata pada siklus I mendapat $69 \%$, kemudian meningkat sebesar $25 \%$ pada siklus II menjadi 94\%.

Keterampilan mengajar guru adalah sebagaimana pendapat Amstrong dkk dalam (Bastian, 2019) yaitu kemampuan menspesifikasi tujuan performasi, kemampuan mendiagnosa murid, keterampilan memilih strategi pengajaran, kemampuan berinteraksi dengan murid, dan keterampilan menilai efektifitas pengajaran. Mansyur (2017) ada beberapa keterampilan dasar mengajar yang harus dikuasai oleh guru atau calon guru dalam proses pembelajaran yaitu: 1) keterampilan bertanya, 2) keterampilan memberi penguatan, 3) keterampilan mengadakan variasi, 


\section{Ella Agustina, Imaniar Purbasari, dan Ristiyani \\ ALAT PERAGA ENGKLEK SEBAGAI UPAYA PENINGKATAN KEMAMPUAN ... \\ WASIS: Jurnal Ilmiah Pendidikan. Volume 1, Nomor 2, November 2020, hlm. 93-98}

4) keterampilan menjelaskan, 5) keterampilan membuka dan menutup pelajaran, 6) keterampilan membimbing diskusi kelompok kecil, 7) keterampilan mengelola kelas, dan 8) keterampilan membimbing diskusi kelompok kecil.

Alat peraga sangat membantu dalam proses pembelajaran karena menyenangkan bagi siswa dan dapat menjadikan kelas semakin aktif, penggunaan alat peraga yang sesuai dapat mempermudah guru dalam penyampaian materi pelajaran dan lebih mudah mencapai tujuan pembelajaran yang telah ditentukan. Sukirno dan Ridwan (2017) menjelaskan proses pembelajaran yang demikian tidak akan menimbulkan kejenuhan pada siswa, sehingga mereka dapat memusatkan perhatian penuh terhadap materi pelajaran. Berdasarkan analisis data disimpulkan bahwa dengan menggunakan alat peraga engklek dapat meningkatkan kemampuan menggali pengetahuan baru siswa dan keterampilan mengajar guru di setiap siklus.

\section{SIMPULAN}

Berdasarkan hasil penelitian tindakan kelas yang dilakukan pada kelas IV SD IT AlHikmah Mayong disimpulkan bahwa dengan menggunakan alat peraga engklek dapat meningkatkan kemampuan menggali pengetahuan baru siswa dan keterampilan mengajar guru.

Kemampuan menggali pengetahuan baru siswa mengalami peningkatan dari siklus I $64 \%$ dan siklus II menjadi $92 \%$, dapat dinyatakan sudah mencapai indikator keberhasilan yaitu 70 dengan ketuntasan belajar klasikal mencapai 75\% atau dengan kualifikasi baik.

Keterampilan mengajar guru terdapat peningkatan pada siklus I memperoleh persentase keberhasilan $70 \%$ dengan kategori cukup, kemudian pada siklus II memperoleh persentase keberhasilan 94\% dengan kategori sangat baik dan dapat dinyatakan telah mencapai indikator keberhasilan yaitu $\geq 75 \%$ dengan kualifikasi minimal baik.

\section{DAFTAR PUSTAKA}

Aliya, Noorina Silmi. 2016. Peningkatan Prestasi Belajar Ilmu Pengetahuan Sosial Siswa Kelas IV Menggunakan Metode Permainan. Jurnal Pendidikan Guru Sekolah Dasar. Edisi 9 Tahun ke-5.
Arikunto, Suharsimi. 2010. Prosedur Penelitian Suatu Pendekatan Praktik. Jakarta: PT Asdi Mahasatya.

Astuti, Minarni Try. 2019. Yuk, Ungkap Idemu Melalui Teks Persuasi hingga Teks Tanggapan. Bandung: Penerbit Duta.

Bastian. 2019. Analisis Keterampilan Dasar Mengajar Guru dalam Melaksanakan Pembelajaran di Sekolah Dasar. Jurnal PAJAR (Pendidikan dan Pengajaran), 3 (6): 1358.

Emda, Amna. 2017. Kedudukan Motivasi Belajar Siswa dalam Pembelajaran. Lantanida Journa, 5 (2): 175.

Fauziah, Amni, dkk. Hubungan Antara Motivasi 2017. Belajar dengan Minat Belajar Siswa Kleas IV SDN Poris Gagas 05 Kota Tangerang. Jurnal JPSD, 4 (2): 48.

Hapidin dan Yenina. 2016. Pengembangan Model Permainan Tradisional dalam Membangun Karakter Anak Usia Dini. Jurnal Pendidikan Usia Dini, 10 (2): 204.

Hastutik Sri. 2015. Penerapan Metode Lawaran Untuk Meningkatkan Keterampilan Dan Motivasi Membaca Huruf Jawa Pada Peserta Didikkelas 3sd 2 Honggosoco Kecamatan Jekulo Kabupaten Kudus Tahun Pelajaran 2014/2015. Refleksi Edukatika : Jurnal Ilmiah Kependidikan, 5 (2).

Hermawan. 2018. Peningkatan Hasil Belajar Menggunakan Permainan Tradisional Pada Tema 3 Subtema 2 Siswa Kelas IV SDN Jongkang Yogyakarta. Yogyakarta: Fakultas Keguruan dan Ilmu Pendidikan. Universitas Sanata Dharma.

Juliarto, F. F., Oktavianti, I., \& Purbasari, I. (2020). Implementasi Media Utangklek Terhadap Peningkatan Hasil Belajar Siswa Sekolah Dasar. WASIS: Jurnal Ilmiah Pendidikan, 1(1), 36-43.

Kurniati, Euis. 2016. Permainan Tradisional dan Perannya dalam Mengembangkan Keterampilan Sosial Anak. Jakarta: Prenadamedia Group (Divisi Kencana). 


\section{Ella Agustina, Imaniar Purbasari, dan Ristiyani \\ ALAT PERAGA ENGKLEK SEBAGAI UPAYA PENINGKATAN KEMAMPUAN ... \\ WASIS: Jurnal Ilmiah Pendidikan. Volume 1, Nomor 2, November 2020, hlm. 93-98}

Kusniati. 2015. Upaya Meningkatkan Keterampilan dan Motivasi Membaca Geguritan Melalui Metode Teatrikalisasi Geguritan Pada Peserta Didik Kelas 6 SD 1 Sadang Kecamatan Jekulo Kabupaten Kudussemester 1 Tahun Pelajaran 2014/2015. Refleksi Edukatika : Jurnal Ilmiah Kependidikan, 5 (2).

Mansyur. 2017. Keterampilan Dasar Mengajar dan Penguasaan Kompetensi Guru (Suatu Proses Pembelajaran Micro). El-Ghiroh, XII (1): 132-139.

Mardayani, Komang Trisna, dkk. 2016. Penerapan Permainan Tradisional Engklek Untuk Meningkatkan Kemampuan Motorik Kasar Kelompok B di PAUD Widhya Laksmi. e-Journal Pendidikan Anak Usia Dini Universitas Ganesha Jurusan Pendidikan Guru Pendidikan Anak Usia Dini, 4 (2): 5.

Marwiyah, dkk. 2018. Perencanaan Pembelajaran Kontemporer Berbasis Penerapan Kurikulum 2013. Yogyakarta: Deepublish (Grup Penerbitan CV Budi Utama).

Mudikawaty, Meity, dkk. 2018. Super Complete $S D / M I$ 4,5,6. Depok: Magenta Media.

Mulia, Dini Siswani dan Suwarno. 2016. PTK (Penelitian Tindakan Kelas) dengan Pembelajaran Berbasis Kearifan Lokal dan Penulisan Artikel Ilmiah di SD Negeri Kalisube, Banyumas. Khazanah Pendidikan: Jurnal Ilmiah Kependidikan, IX (2): 3-4.

Murdiyanto, Tri dan Yudi Mahatma. 2014. Pengembangan Alat Peraga Matematika Untuk Meningkatkan Minat dan Motivasi Belajar Matematika Siswa Sekolah Dasar. Jurnal Sarwahita, 11 (1): 39.

Murtono. 2014. Eksperimentasi Model Kooperatif CIRC dan JIGSAW Untuk Peningkatan Keterampilan Membaca Ditinjau Dari Kemampuan Logika Berbahasa. Refleksi Edukatika : Jurnal Ilmiah Kependidikan, 4 (2): 1-12.

Nazilah, Fauziatun, dkk. 2017. Meningkatkan Kemampuan Siswa dalam Menggali Informasi dari Teks Wawancara dalam
Bahasa Indonesia Tulis dengan Role Playing (Penelitian Tindakan Kelas IV B MI Ketib Kecamatan Sumedang Utara Kabupaten Sumedang). Jurnal Pena Ilmiah, 2 (1): 131-132.

Prasetyawati, Ririn. 2015. Pengembangan Prototipe Buku Enam Permainan Tradisional Jawa Untuk Membangun Karakter Anak. Yogyakarta: Fakultas Keguruan dan Ilmu Pendidikan. Universitas Sanata Dharma.

Rini Arum Puspita. 2018. Peningkatan Hasil Belajar Tema 1 Subtema 3 Menggunakan Metode Permainan Tradisional Pada Siswa IV SD N Selomulyo. Yogyakarta: Fakultas Keguruan dan Ilmu Pendidikan. Universitas Sanata Dharma.

Rusmawati. 2017. Penggunaan Alat Peraga Langsung Pada Pembelajaran Matematika dengan Materi Pecahan Sederhana Untuk Meningkatkan Hasil Belajar Siswa. Suara Guru: Jurnal Ilmu Pendidikan Sosial, Sains, dan Humaniora, 3 (2): 309.

Sari, Yolanda Dana Kumala., Chamisijatin, Lise., dan Santoso, Budi. 2019. Peningkatan Keterampilan Membaca Puisi Siswa Kelas IV Dengan Model Demonstrasi Didukung Media video Pembelajaran Di SDN 1 Sumbersari Kota Malang. Refleksi edukatika: Jurnal Ilmiah Kependidikan, 9 (2): 156-163.

Sukirno dan Daenuri Ridwan. 2017. Optimalisasi Hail Belajar IPS Melalui Permainan Tradisional. JIPSINDO. 1 (4): 33.

Supriyati. 2015. Metode Bermain Peran Sebagai Upaya Meningkatkan Kemampuan Berbahasa Jawapada Peserta Didik Kelas 6 SD 5 Hadipolo Kecamatan Jekulo Kabupaten Kudus Semester 1 Tahun Pelajaran 2014/2015. Refleksi Edukatika : Jurnal Ilmiah Kependidikan, 5 (2).

Wiranti, Dwiana Asih dan Diah Ayu Mawarti. 2018. Keefektifan Permainan Engklek Dalam Mengembangkan Kemampuan Motorik Kasar Anak Usia Dini. Refleksi Edukatika : Jurnal Ilmiah Kependidikan, 9 (1): 66-74. 
Ella Agustina, Imaniar Purbasari, dan Ristiyani

ALAT PERAGA ENGKLEK SEBAGAI UPAYA PENINGKATAN KEMAMPUAN ...

WASIS: Jurnal Ilmiah Pendidikan. Volume 1, Nomor 2, November 2020, hlm. 93-98

Yogyantoro, Angger. 2016. Peningkatan

Keterampilan Menulis Karangan

Deskripsi Menggunakan Media Diorama

Siswa Kelas IV. Jurnal Pendidikan Guru

Sekolah Dasar. 38 (5): 2. 